Fernández, J.P., Chaar, F.B., Epherra, L., González-Aravena, J.M., \& Rubilar, T. (2021). Embryonic and larval development is conditioned by water temperature and maternal origin of eggs in the sea urchin Arbacia dufresnii (Echinodermata: Echinoidea). Revista de Biología Tropical, 69(S1), 452-463. DOI 10.15517/ rbt.v69iSuppl.1.46384

DOI 10.15517/rbt.v69iSuppl.1.46384

\title{
Embryonic and larval development is conditioned by water temperature and maternal origin of eggs in the sea urchin Arbacia dufresnii (Echinodermata: Echinoidea)
}

\author{
Jimena Pía Fernández $z^{1,2}$ \\ Florencia Belén Chaar ${ }^{1,2,3}$ \\ Lucía Epherra $^{2}$ \\ Jorge Marcelo González-Aravena ${ }^{4}$ \\ Tamara Rubilar ${ }^{1,2 *}$
}

1. Laboratory of Chemistry of Marine Organisms, Instituto Patagónico del Mar, National University of Patagonia San Juan Bosco, Bv. Almte. Brown 3051, Puerto Madryn, Argentina; rubilar@cenpat-conicet.gob.ar (*Correspondence).

2. Biological Oceanography Laboratory, Centro para el Estudio de Sistemas Marinos, Centro Nacional Patagónico, Consejo Nacional de Investigaciones Científicas y Técnicas, Blvd. Almte. Brown 2915, Puerto Madryn, Argentina; jpfernandez@cenpat-conicet.gob.ar; lepherra@cenpat-conicet.gob.ar

3. National University of Patagonia San Juan Bosco, Blvd. Almte. Brown 3051, Puerto Madryn, Argentina; chaar@gmail.com

4. Scientific Department, Chilean Antarctic Institute, Plaza Muñoz Gamero 1055, Punta Arenas, Chile; mgonzalez@inach.cl

Received 16-VII-2020. Corrected 30-X-2020. Accepted 02-XI-2020.

\begin{abstract}
Introduction: Embryonic and larval development in sea urchins is highly dependent on maternal nutritional status and on the environmental conditions of the seawater. Objective: To compare the development of Arbacia dufresnii in two different water temperatures and in progeny with varying maternal origins. Methods: We induced $A$. dufresnii females and males from Nuevo Gulf to spawn, collected the eggs of each female individually (progeny), separated them into two seawater temperatures $\left(12\right.$ and $\left.17^{\circ} \mathrm{C}\right)$, and fertilized them. We recorded the percentage of fertilized eggs and embryos per developmental stage according to time, temperature and progeny. We measured larval growth by total length (TL) and midline body length (M) according to time post fecundation (DPF), temperature, and progeny. Results: Temperature did not affect fertilization, but embryo development was faster and more synchronized in the high temperature treatment. The generalized linear models indicate that embryo development depends on a quadruple interaction between the embryonic stage, time (h), seawater temperature and progeny. Larval growth was faster, producing larger larvae at the highest temperature. Larval growth depends on a triple interaction between time (DPF), seawater temperature and progeny. Conclusions: We found a temperature and progeny impact during embryonic and larval development and, in both cases, these factors generate a synergistic effect on developmental timing and larval size. This probably provides a survival advantage as a more rapid speed of development implies a decrease in the time spent in the water column, where the sea urchins are vulnerable to biotic and abiotic stressors.
\end{abstract}

Key words: Echinoderm; Echinoidea; parental provisioning; thermal effect; early life stages; larval growth. 
Embryonic and larval development in sea urchins is highly dependent on maternal nutritional status (George, Cellario \& Fenaux, 1990; Byrne, Sewell, \& Prowse, 2008a; Byrne et al., 2008b; Wong, Kozal, Leach, Hoshijima \& Hofmann, 2019) and on the environmental seawater conditions in which they develop (Sewell \& Young, 1999; Gibson, Atkinson, Gordon, Smith, \& Hughes, 2011; Przeslawski, Byrne \& Mellin, 2015). Maternal nutritional status depends on food availability, which varies amongst regions and sea urchin populations (George et al.,1990; Epherra et al., 2015; Wong et al., 2019). During the gametogenesis, these nutritional reserves transfer from the female to the eggs (Walker, Lesser, Unuma, 2013). Therefore, the nutritional reserves among populations may vary and, as a result, the quality and quantity of eggs (George et al., 1990; Epherra et al., 2015; Wong et al., 2019). As in other sea urchins, in the Arbacia species, the quality of eggs influences the development and survival of the offspring. In Arbacia lixula, better maternal nutritional status has been related to the high protein and lipid content of the eggs and to larval survival (George et al., 1990). However, in the Arbacia species, the available data relating to these topics is very limited and usually refers to A. lixula (Gianguzza, 2020).

Sea urchins embryos and larvae develop under the influence of many environmental factors. Seawater temperature is an important factor, as it has a profound impact on many physiological processes (Sewell \& Young, 1999; Byrne, 2011; Przeslawski et al., 2015). Temperature affects the kinetics of biochemical reaction and, therefore, the metabolic and development rate but, on the other hand, it can also alter seawater $\mathrm{pH}$ or cause oxidative stress and other cellular stresses (Byrne, 2011; Irvine, 2020). In A. lixula, reproduction and larval development is enhanced by high temperatures (Privitera, Noli, Falugi \& Chiantore, 2011; Wangensteen, Turon, Casso \& Palacín, 2013) and some studies indicate that this is a thermophilus species (Pérez-Portela et al. 2019; Gianguzza et al., 2011). However, all organisms have a limited body temperature range in which they are functional (Pörtner, 2002). Beyond the extremes of this range, organisms experience functional constraints and cannot survive (García, Clemente \& Hernández, 2015). However, more studies are still needed to determine how other Arbacia species react to an increase in temperature during the different life stages.

The sea urchin Arbacia dufresnii is an abundant species in the South Atlantic and Pacific Oceans (Bernasconi, 1947, 1966; Lessios et al., 2012; Brogger et al., 2013). It presents a large distribution range from the coast of Buenos Aires $\left(35^{\circ} \mathrm{S}\right)$ to Puerto Montt in Chile $\left(42^{\circ} \mathrm{S}\right)$ and the close-lying islands of the South Atlantic Ocean (Bernasconi, 1947, 1966; Brogger et al., 2013). This wide range distribution also exposes the different populations to different seawater temperatures (ranging from $23{ }^{\circ} \mathrm{C}$ to $4{ }^{\circ} \mathrm{C}$ ). Food availability and feeding varies according to the environment the population inhabits, varying from mainly herbivore to mainly carnivorous (Penchaszadeh \& Lawrence, 1999; Newcombe, Cárdenas \& Geange, 2012; Epherra, 2016). The population of $A$. dufresnii at Nuevo Gulf experiences a temperature range from $17.35{ }^{\circ} \mathrm{C}$ to $10.41{ }^{\circ} \mathrm{C}$ throughout the year (monthly mean) (Rivas, Pisoni \& Dellatorre, 2016). In this population, the gametogenic cycle starts in the fall and spawning takes place in the spring and summer (Brogger et al., 2013; Epherra et al., 2015). During the spawning period, the seawater temperature increased from $12{ }^{\circ} \mathrm{C}$ in early spring to $17{ }^{\circ} \mathrm{C}$ by the end of summer (Rivas et al., 2016). Some studies have been carried out on the first stages of the life cycle of $A$. dufresnii (Bernasconi, 1942; Brogger, 2005; Fernández, Epherra, Sepúlveda \& Rubilar, 2019). Bernasconi (1942) first cultured A. dufresnii embryos and early larvae at a temperature of 28 to $30^{\circ} \mathrm{C}$, and later, Brogger (2005) cultured early embryos and larvae at $26-28^{\circ} \mathrm{C}$. In both cases, the cultured organisms started to develop, but after a few days they showed noticeable signs of stress, stopped growing and died. The temperatures used in these studies exceeded the temperature of the natural habits and, possibly, 
the range geographic distribution of the species. Fernández et al. (2019), cultured embryos and larvae of this species up to the 8-armed echinopluteus, but only at $17^{\circ} \mathrm{C}$. It can, then, be concluded that more information is needed to understand how this species reacts to the different temperatures present in the environments it inhabits. The aim of this work was to compare the embryonic and larval development of A. dufresnii at Nuevo Gulf exposed to the two seawater temperatures normally found in the sea during the spawning period $\left(12\right.$ and $\left.17^{\circ} \mathrm{C}\right)$, and to analyze the responses in progeny with different maternal origins.

\section{MATERIALS AND METHODS}

Collection of sea urchins: Arbacia dufresnii individuals $($ Mean $=33.64 \pm 1.99 \mathrm{SD} \mathrm{mm}$ diameter) were collected $(\mathrm{N}=10)$ on February $3^{\text {rd }} 2017$ from Bahía Kayser, Nuevo Gulf (42 46'44" S; 64 59'52" W) and transported to the Experimental Aquarium at the CENPATCONICET at Puerto Madryn.

Experimental design: Individuals were acclimated for $24 \mathrm{~h}$ in the aquarium. Four females and four males were used for the study. The spawning was induced by the injection in the peristomal membrane of $0.3 \mathrm{ml}$ of a $0.55 \mathrm{M} \mathrm{KCl}$ solution (Ettensohn, 2017). The eggs of each female were individually collected on an aqueous medium (called progeny one to four) and quantified in triplicate in a Sedgewick-Rafter chamber using a Leica DM 2500 microscope. The eggs of each progeny were separated into two seawater temperatures $\left(12{ }^{\circ} \mathrm{C}\right.$ and $\left.17^{\circ} \mathrm{C}\right)$ to obtain eight experimental groups of 100000 eggs each, and they were placed in $100 \mathrm{ml}$ of sea water filtered up to 1 $\mu \mathrm{m}$ and sterilized with UV light. Male gametes were dry harvested in a single container and kept on ice until used to preserve their viability (Ettensohn, 2017). To fertilize the eggs of each experimental group, sperm was used at a 1: 100,000 v/v dilution (around 300: 1 spermegg ratio) and, then, gently mixed, according to Fernández et al. (2019). After $30 \mathrm{~min}$, two seawater changes were performed in order to remove the excess sperm. Fertilization success was recorded based on the presence of the fertilization envelope on the eggs, using an optical microscope (Leica DM 2500) and a Bogorov chamber. In samples of $100 \mu \mathrm{l}$ from each experimental group, the percentage of fertilization was calculated as: (fertilized eggs / total eggs) * 100. For the next $48 \mathrm{~h}$, the developing embryos of each experimental group were kept with constant and gentle aeration, at a salinity of 34-35 ppm, and a photoperiod $12 \mathrm{~h}$ of light and $12 \mathrm{~h}$ of darkness. In samples of $100 \mu \mathrm{l}$ from each experimental group, the percentage of embryos in the different developmental stages was determined according to Gilbert (2005) at different times $(2,3,4,6,12,24,30$, and $48 \mathrm{~h})$. Progeny four resulted in low viable embryos, and they were, consequently, excluded from the embryo stages determination. After $48 \mathrm{~h}$, 200 swimming larvae of each experimental group were transferred to a new container with $100 \mathrm{ml}$ of sea water filtered up to $1 \mu \mathrm{m}$ and sterilized with UV light. In this case, as only viable embryos reach the larva stage, the larvae from progeny four were considered to analyze larval growth. The larvae were kept with constant aeration, at a salinity of 34-35 ppm, photoperiod $12 \mathrm{~h}$ of light and $12 \mathrm{~h}$ of darkness, and after 3 days post fecundation (DPF), the larvae were fed daily with a mix of microalgae Tetraselmis suecica and Isochrysis galbana (10 000 cells.ml ${ }^{-1}$ ). To maintain water quality, $50 \%$ of the seawater in each container was replaced every $48 \mathrm{~h}$. In order to assess larval growth over time, between three to four larvae of each experimental group were taken at 2, 3, 4, 7, 10, 13, 19 and 22 DPF. Each larva was photographed using a Leica DM 2500 optical microscope, Leica ICC50W digital camera and LAS EZ B4.5.0.418 Software. Images were analyzed by using the software Image-J. Total length (TL) and midline body length (M) were used to monitor larval growth (Fig. 1).

Data analysis: Differences in the fertilization between treatments were analyzed by using one-way ANOVA. Normality was 
tested by using Kolmogorov-Smirnoff and the homoscedasticity of variance was tested using the Levene test (Zar, 1984). To analyze the effect of temperature, time (DPF) and progeny (maternal origin of the eggs) in the abundance of developmental embryonic stages, a Generalized Linear Model (GLM) was applied (McCullagh, 1984). We proposed nineteen different models starting with a null model (simpler model without any explanatory variable). We increased complexity into the models to end up with a complex quadrupole interaction model. To analyze the effect of temperature, time (DPF) and progeny (maternal origin of the eggs) on the variables of larval growth (TL and M), a GLM was also applied. We proposed twelve different models starting with a null model. We increased complexity into the models to end up with a complex triple interaction model. In both cases, the best model was selected under the Akaike criterion taking into account the residual analyzes, the explained variances (deviations) and the principle of parsimony or normality. All GLM analyzes were performed with the free software RStudio (version 3.5.1), and for the ANOVA, Kolmogorov-Smirnoff and Levene tests, the software InfoStat 2016 was also used.

\section{RESULTS}

Fertilization: The percentage of fertilization was not significantly different between temperature treatments (Mean $17{ }^{\circ} \mathrm{C}: 92.44 \pm$ 3.71; Mean $12{ }^{\circ} \mathrm{C}: 88.24 \pm 7.03$ ) (ANOVA, $\mathrm{F}_{1,5}$ $=0.28, \mathrm{P}=0.6252$ ).

Embryonic development: At both temperature treatments, a majority of normal embryonic development was observed, with a low occurrence of abnormal phenotypes. At the highest temperature, a synchronized development was observed (Fig. 2). This is particularly noticeable at 6 and $12 \mathrm{~h}$, where more than $97 \%$ of the embryos were found to be at the same stage of development. However, and in contrast, at the lowest temperature, there was a major heterogeneity of embryonic development at all times. This applied in particular between 3 and 48 hours, when the abundance of each stage did not exceed $60 \%$ in any case. At the same time, at $17{ }^{\circ} \mathrm{C}$, the development of the embryos was faster than at $12{ }^{\circ} \mathrm{C}$ (Fig. 2). This difference in development time is evident from the beginning of the embryonic development and becomes more noticeable over time. On the other hand, there was a progeny effect which was more noticeable over time. Progeny three showed a faster development at both temperatures, and progeny two showed the slower development. At $48 \mathrm{~h}$ in the $17{ }^{\circ} \mathrm{C}$ treatment, most of the organisms in progeny 3 were in the larval stage, while in progeny 2 the majority were at the blastula stage. In figure 2, this effect can be observed as two predominant columns and an increase in the standard error at $48 \mathrm{~h}$ in the $17{ }^{\circ} \mathrm{C}$ treatment. This heterogeneity is not observed within the same progeny; however, it can be seen between the progeny of different maternal origins. The GLM analysis for embryonic development confirms these observations. Table 1 presents the results of

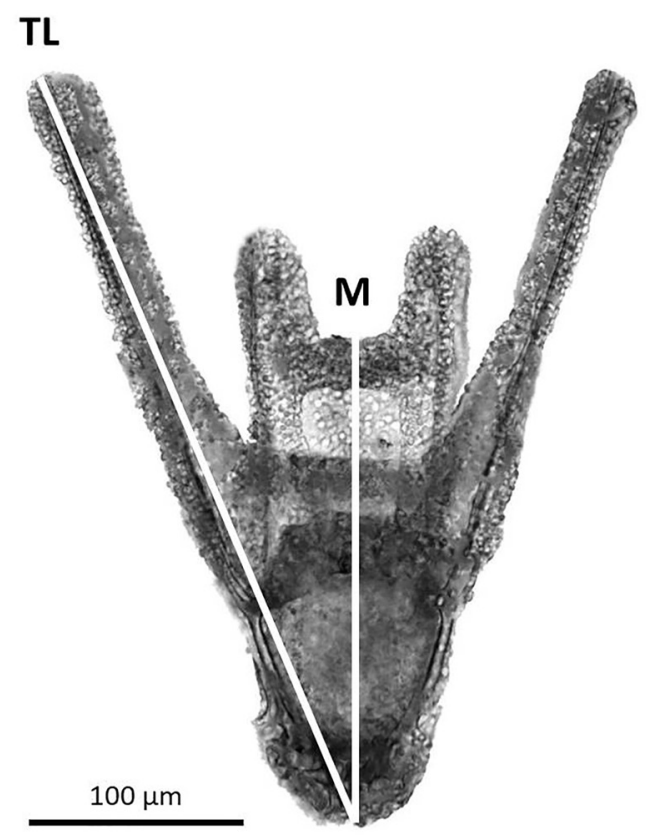

Fig. 1. Measurements in the images of the larvae of $A$. dufresnii. TL: Total length. M: Midline body length. 
TABLE 1

Arbacia dufresnii. GLM analysis for embryonic development stages. In bold, the models with the best fit according to the Akaike information criterion (AIC)

\begin{tabular}{rlcr} 
& \multicolumn{1}{c}{ Model } & d.f. & \multicolumn{1}{c}{ Akaike } \\
1 & Null & 1 & 16868.87 \\
2 & Stage & 8 & 14926.23 \\
3 & Time & 9 & 16884.86 \\
4 & Progeny & 3 & 16872.86 \\
5 & Temperature & 3 & 16872.86 \\
6 & Stage + Time & 16 & 14942.23 \\
7 & Stage + Progeny & 10 & 14930.23 \\
8 & Stage + Temperature & 10 & 14930.23 \\
9 & Stage x Time & 72 & 4064.65 \\
10 & Stage x Progeny & 24 & 14652.49 \\
11 & Stage x Temperature & 24 & 14652.49 \\
12 & Stage x Time + Stage x Progeny & 88 & 3790.91 \\
13 & Stage x Time + Stage x Temperature & 88 & 3790.91 \\
14 & Stage x Progeny + Stage x Temperature & 24 & 14652.49 \\
15 & Stage x Time x Progeny & 216 & $\mathbf{3 5 5 7 . 6 7}$ \\
16 & Stage x Time x Temperature & 216 & $\mathbf{3 5 5 7 . 6 7}$ \\
17 & Stage x Progeny x Temperature & 24 & 14652.49 \\
18 & Stage x Time+ Stage x Progeny + Stage x Temperature & 88 & 3790.91 \\
19 & Stage x Time x Progeny x Temperature & 216 & $\mathbf{3 5 5 7 . 6 7}$ \\
\hline
\end{tabular}

the GLM analysis for embryonic development. Even though there were three models with the same AIC, the residuals analysis showed that the most complex model, including the quadrupole interaction between the embryonic stage, time (hours), seawater temperature and progeny, was the best fit for the data. This indicates that the embryonic stage is influenced by, all of these factors.

Larval growth: A majority of normal larval development was observed in both of the temperature treatments showing a lower occurrence of abnormal phenotypes with the 17 ${ }^{\circ} \mathrm{C}$ treatment. Larvae total length (TL) and the midline body length $(\mathrm{M})$ increased in both temperature treatments over time but in a different manner (Fig. 3). At $17{ }^{\circ} \mathrm{C}$, larvae increased in size more rapidly and the larvae were larger than at $12{ }^{\circ} \mathrm{C}$. After a rapid increase in length, the larvae experienced a plateau and, then, increased again at $17{ }^{\circ} \mathrm{C}$. In contrast, at $12{ }^{\circ} \mathrm{C}$ there was an initial increase but this increase took place during a longer period of time, and the plateau was also longer.

On the other hand, we also observed a progeny effect in larval growth which became more noticeable in TL over time. As seen in figure 3, this effect can be observed especially at $22 \mathrm{DPF}$ as an increase in the standard error. However, this heterogeneity occurs primarily between progeny of different maternal origins. The GLM analysis for larval growth confirms these observations. Table 2 presents the results of the GLM analysis for larval growth (TL and $\mathrm{M})$. The most complex model, which included the triple interaction between the time (DPF), seawater temperature and progeny, was the best fit for the data, indicating that larval growth is influenced by all of these factors.

\section{DISCUSSION}

There is a wide range of environmental conditions inhabited by sea urchins and in which their embryos and larvae must endure. 

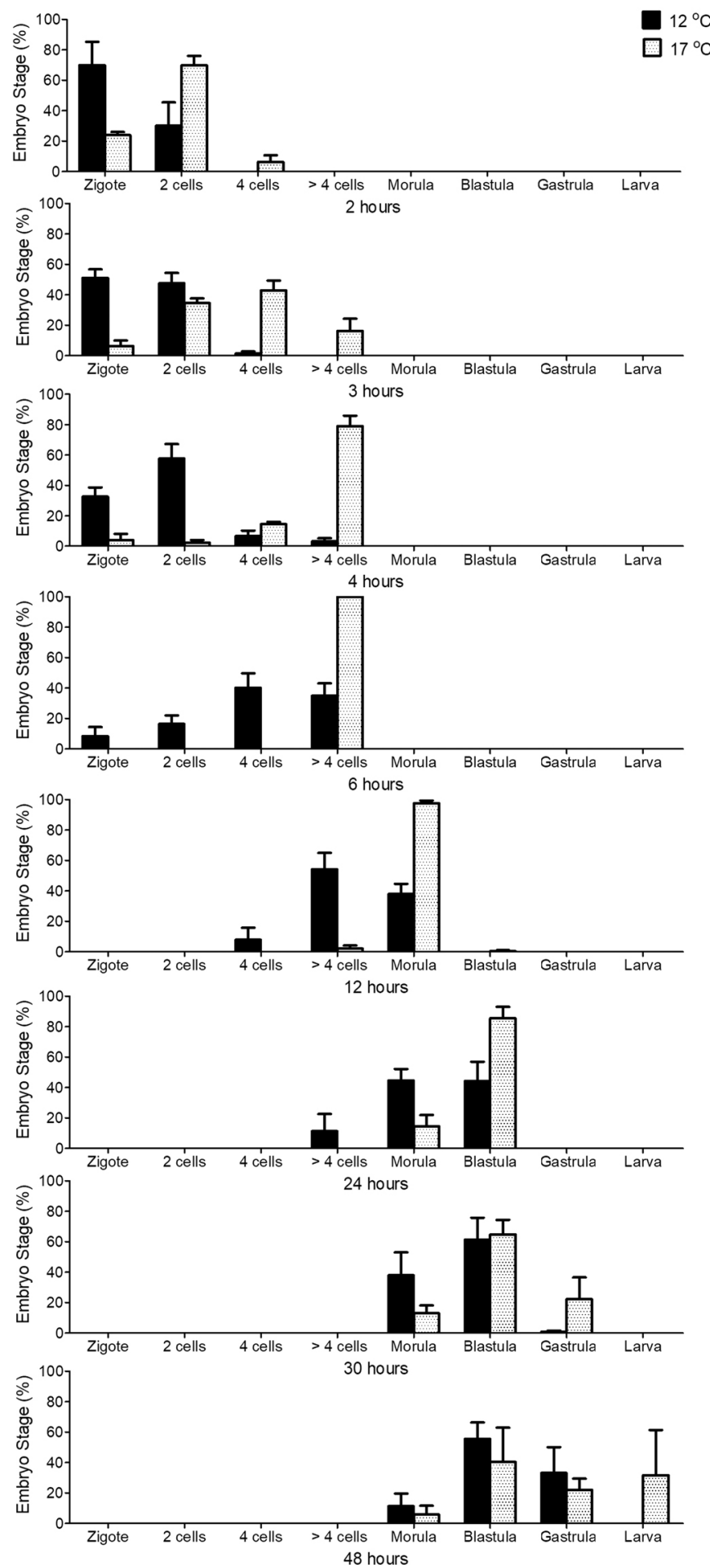

Fig. 2. Arbacia dufresnii. Percentage of embryonic stages during the first $48 \mathrm{~h}$ at two different seawater temperatures. The bars indicate mean \pm standard error values ( $\mathrm{n}=3$ progenies), at the two temperatures analyzed $\left(12\right.$ and $\left.17^{\circ} \mathrm{C}\right)$. 
TABLE 2

Arbacia dufresnii. GLM analysis for larval growth (Larvae total length TL, and Midline body length M) over time (DPF). In bold, the models with the best fit according to the Akaike information criterion (AIC)

\begin{tabular}{rlccc}
\multicolumn{1}{c}{ Model } & d.f. & TL Akaike & M Akaike \\
1 & Null & 1 & 6950.633 & 3035.320 \\
2 & Temperature & 2 & 6750.147 & 2981.955 \\
3 & DPF & 9 & 4519.118 & 2476.731 \\
4 & Progeny & 4 & 6620.148 & 2887.862 \\
5 & Temperature + DPF & 10 & 4096.245 & 2368.619 \\
6 & Progeny + DPF & 12 & 3966.739 & 2279.837 \\
7 & Temperature + Progeny & 5 & 6422.527 & 2834.999 \\
8 & Temperature * DPF & 18 & 3743.943 & 2284.972 \\
9 & Progeny * DPF & 35 & 3292.358 & 2123.422 \\
10 & Temperature * Progeny & 8 & 6025.142 & 2776.841 \\
11 & DPF + Temperature + Progeny & 13 & 3535.150 & 2166.551 \\
$\mathbf{1 2}$ & DPF * Temperature * Progeny & $\mathbf{6 6}$ & $\mathbf{2 1 0 0 . 1 0 1}$ & $\mathbf{1 8 8 5 . 4 5 5}$ \\
\hline
\end{tabular}
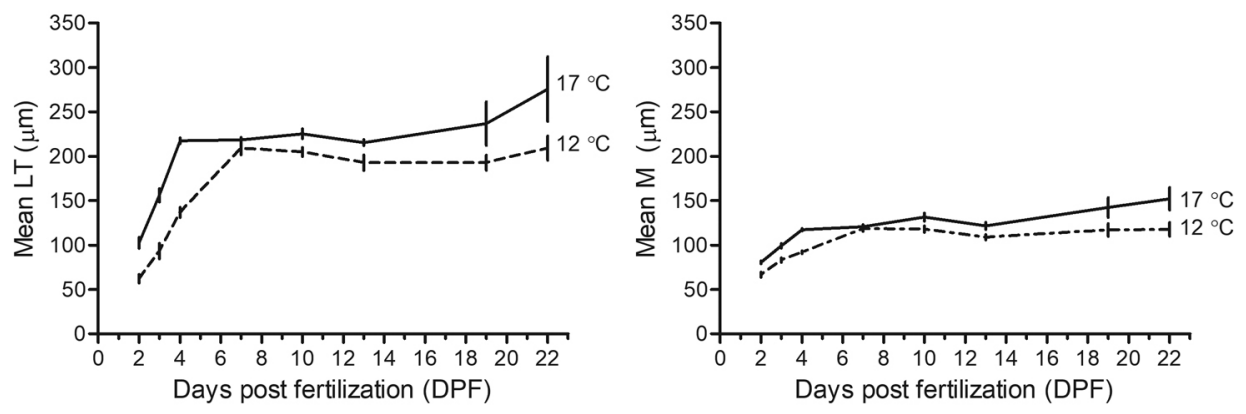

Fig. 3. Larvae Growth. Larvae total length (TL) and Midline body length (M) (Mean \pm SEM, $n=3$ progenies) over time (DPF) in $17^{\circ} \mathrm{C}$ and $12{ }^{\circ} \mathrm{C}$ treatments.

Early life stages are one of the most delicate moments in the life cycle of any organism, and temperature plays a fundamental role in these stages (Byrne et al., 2009). Additionally, there is strong evidence that the thermal acclimatization of the parental females influences the thermal tolerance of fertilization and the development of their progeny (Fujisawa, 1995; O'Connor \& Mulley, 1977; Karelitz, Lamare, Patel, Gemmel \& Uthicke, 2020). However, there is little knowledge regarding these external factors in terms of the development of $A$. dufresnii (Brogger, 2005; Catarino, De Ridder, Gonzalez, Gallardo \& Dubois, 2012).

The population of $A$. dufresnii inhabiting the Nuevo Gulf starts to spawn in spring when the seawater temperature is around $12{ }^{\circ} \mathrm{C}$ and there is continuous spawning during the summer when the seawater temperature increases to $17{ }^{\circ} \mathrm{C}$ (Epherra et al., 2015; Rivas et al., 2016). In this way, spawned eggs experience different seawater conditions in terms of the timing of spawning. Our results show that at both seawater temperatures the percentage of fertilization registered was high and similar, indicating that fertilization was not affected by the analyzed temperatures. Other species of sea urchins have been reported to exhibit a broad tolerance to warming in egg fertilization $(+6$ ${ }^{\circ} \mathrm{C}$ above the ambient temperature) (Sewell \& Young, 1999; Byrne et al., 2009; Byrne, 2012). The sperm:egg ratio is species-specific and can 
vary from 10: 1 to $1500: 1$ for the same species, depending on the experimental conditions (Byrne et al., 2009; Ericson et al., 2012). The sperm:egg ratio used (300:1) (Fernández et al., 2019) did not affect the fertilization of eggs even with a $5{ }^{\circ} \mathrm{C}$ thermal difference between treatments. However, it is possible that with a lower ratio, fertilization varies between the temperatures analyzed.

An increase in seawater temperature is usually related to an acceleration of development and the growth rate in other sea urchin larvae (O'Connor et al., 2007; Rahman, Rahman, \& Uehara, 2007; Rahman, Tsuchiya, \& Uehara, 2009). Our results show that $A$. dufresnii developed more rapidly and synchronized at $17{ }^{\circ} \mathrm{C}$ rather than at $12{ }^{\circ} \mathrm{C}$. A rapid embryonic hatch allows for planktotrophic larvae development and prompt feeding, increasing the chance for survival. Due to the fact that phytoplankton blooms are found in the spring and summer at Nuevo Gulf (De Vido De Mattio, 1980; Esteves, de Vido de Mattio, Cejas \& Frontali, 1981; Pastor \& Bala, 1995), a rapid development by the end of the summer may ensure food supply for the larvae. However, progeny is also important since produce a synergistic interaction. The fact that analyzing these factors separately the AIC values were the same, indicates that there is a strong maternal influence on the progeny during embryonic development. The females' nutritional status affects their gonadal development (Thompson, 1983; Lemire \& Himmelman, 1996; Walker \& Lesser, 1998; Rubilar et al., 2016). Eggs from females with a good nutritional status should show a high quantity and quality of nutrients, which will provide sufficient energy and other nutrients until the organism can successfully feed on their own (Byrne et al., 2008b). The differences found during the embryonic development according to progeny may be due to differences in the nutritional status among females in Nuevo Gulf where food is not abundant (Epherra et al., 2015; Parra et al., 2015). In this way, embryos of $A$. dufresnii are affected by endogenous (nutrients) and exogenous (temperature) factors which interact simultaneously over time.

The sea urchin larvae growth rate is affected by several factors, such as salinity, $\mathrm{pH}$, solar radiation, seawater temperature and food availability (Metaxas, 2013; Przeslawski et al., 2015). The larvae of $A$. dufresnii grew faster and larger at $17{ }^{\circ} \mathrm{C}$ than at $12{ }^{\circ} \mathrm{C}$, suggesting that development appears to be more efficient at higher temperatures. The temperature may increase survival as it implies a decrease in the time spent at the water column where the sea urchins are vulnerable to biotic and abiotic stressors (Uthicke, Schaffelke \& Byrne, 2009; Hardy et al., 2014; Przesławski et al., 2015). Because of this, some studies indicate that an increase in seawater temperature can favor the development of embryos and larvae in $A$. lixula (Privitera et al., 2011; Wangensteen et al., 2013; Gianguzza et al., 2014; Visconti et al., 2017). Phytoplankton blooms in the Nuevo Gulf during early spring are longer than in late summer (Esteves et al., 1981; Esteves, Santinelli, Sastre, Díaz \& Rivas, 1992), generating longer periods of food availability for A. dufresnii larvae in the spring than in the late summer. However, at $12{ }^{\circ} \mathrm{C}$ larvae have a longer period of development than at 17 ${ }^{\circ} \mathrm{C}$. This may generate an increased survival rate of larvae, due to food availability at low temperatures and, due to the speed of development at higher temperatures in Nuevo Gulf. In $A$. lixula, discrepancies were found in the optimal temperature for recruitment between populations from different regions (Privitera et al., 2011), probably indicating different strategies to achieve metamorphosis, depending on regional environmental factors, such as high temperature or available food (Privitera et al., 2011; Gianguzza, 2020). On the other hand, our results show that in $A$. dufresnii there is a strong progeny influence on larvae development. Both temperature and progeny are important factors and interact with each other, producing a synergistic effect. This indicates that other factors, in addition to abiotic factors, are important to larval survival and that endogenous factors also play an important role. 
Unlike other sea urchins, Arbacia species are found in tropical, temperate, and subantarctic areas (Gianguzza, 2020). Some studies indicate that $A$. lixula is a thermophilic (heat-tolerant) species (Gianguzza et al., 2011; Gianguzza et al., 2014; Pérez-Portela et al. 2019), and may develop normally in an amplitude of $10{ }^{\circ} \mathrm{C}$, with local differences depending on the thermal history prior to spawning (Gianguzza, 2020). A. dufresnii also presents a large distribution with different seawater temperatures (ranging from $23{ }^{\circ} \mathrm{C}$ to $4{ }^{\circ} \mathrm{C}$ ). Along regions, the different populations show spatial and temporal differences in their reproductive cycle. This plasticity may be responsible for its wide distribution and adaptation to different environments. There is scarce data regarding the thermal tolerance during the development of A. dufresnii. However, numerous studies have shown that for each species there is an optimal temperature range for fertilization and development, and that this thermal tolerance is closely related to the thermal acclimatization of the parental females (Karelitz et al., 2020). This may explain the success in fertilizing eggs but the failed larval development at $26-28^{\circ} \mathrm{C}$ as regards $A$. dufresnii from Nuevo Gulf (Brogger, 2005). On the other hand, our results show that within the optimal temperature range, the higher temperature generates faster development and larger larvae. However, there is still a lack of data regarding other factors, impacting the development of $A$. dufresnii and the possible interactions that can occur between such factors. A clear example of one such interaction is how changes in temperature, as well the oceanic acidification expected to take place in the next decades, will affect the distribution of this species.

Ethical statement: authors declare that they all agree with this publication and made significant contributions; that there is no conflict of interest of any kind; and that we followed all pertinent ethical and legal procedures and requirements. All financial sources are fully and clearly stated in the acknowledgements section. A signed document has been filed in the journal archives.

\section{ACKNOWLEDGMENTS}

We are grateful to the diver Ricardo Bebo Vera for the collection of the sea urchins, to Mariano Moris for helping with the experiments and to Kathleen C. Anderson for the revision of the English. This work was undertaken with funds from PIP 0352/14, PICT 2018-1729. The sea urchins were collected by the Provincial Permit N586/18.

\section{RESUMEN}

\section{El desarrollo embrionario y larvario está condicionado por la temperatura del agua y el origen materno de los huevos en el erizo de mar Arbacia dufresnii (Echinodermata: Echinoidea)}

Introducción: El desarrollo embrionario y larvario de los erizos de mar depende en gran medida del estado nutricional materno y de las condiciones ambientales del agua de mar. Objetivo: Comparar el desarrollo de Arbacia dufresnii en dos temperaturas de agua diferentes y en progenies con diferentes orígenes maternos. Métodos: indujimos a las hembras y machos de A. dufresnii del Golfo Nuevo a desovar, recolectamos los huevos de cada hembra individualmente (progenie), los separamos en dos temperaturas de agua de mar $\left(12\right.$ y $\left.17^{\circ} \mathrm{C}\right)$ y los fertilizamos. Registramos el porcentaje de óvulos fecundados y el porcentaje de embriones por etapa de desarrollo según tiempo, temperatura y descendencia. Medimos el crecimiento larvario según la longitud total (TL) y la longitud corporal de la línea media (M) de acuerdo con el tiempo en días post fecundación, la temperatura y la progenie. Resultados: La temperatura no afectó la fertilización, pero el desarrollo del embrión fue más rápido y más sincronizado en el tratamiento de alta temperatura. Los modelos lineales generalizados indican que el desarrollo del embrión depende una interacción cuádruple entre el estadio embrionario, el tiempo (h), la temperatura del agua de mar y la progenie. El crecimiento larvario fue más rápido, produciendo larvas más grandes a la temperatura más alta. El crecimiento de las larvas depende de una triple interacción entre el tiempo (DPF), la temperatura del agua de mar y la progenie. Conclusiones: Encontramos un impacto en la temperatura y en la progenie durante el desarrollo embrionario y larvario y, en ambos casos, estos factores generaron un efecto sinérgico sobre el tiempo de desarrollo y el tamaño de las larvas. Esto probablemente proporciona una ventaja de supervivencia, ya que una velocidad de desarrollo más rápida implica una disminución en el tiempo que pasan en 
la columna de agua, donde los erizos de mar son vulnerables a los factores estresantes bióticos y abióticos.

Palabras clave: Equinodermos; reproducción; aprovisionamiento parental; efecto térmico; estadios tempranos del desarrollo; crecimiento larval.

\section{REFERENCES}

Bernasconi, I. (1942). Primeros estados larvales de Arbacia dufresnii (Blv). Physis: Revista de la Sociedad Argentina de Ciencias Naturales, 19(53), 305-317.

Bernasconi, I. (1947). Distribución geográfica de los equinoideos argentinos. Anales de la Sociedad Argentina de Estudios Geográficos, 6, 97-114.

Bernasconi, I. (1966). Los Equinodermos recolectados por el Walther Herwig en el Atlántico Sudoeste. Hidrobiológica, 3, 289-334.

Brogger, M. I. (2005). Biología reproductiva del erizo verde Arbacia dufresnii (Blainville, 1825) en las costas del Golfo Nuevo, Patagonia (Bachelor thesis). Universidad de Buenos Aires, Argentina.

Brogger, M., Gil, D. G., Rubilar, T., Martínez, M., Díaz de Vivar, M. E., Escolar, M., ... Tablado, A. (2013). Echinoderms from Argentina: Biodiversity, distribution and current state of knowledge. In J. J. Alvarado \& F. A. Solís-Marín (Eds.), Echinoderm Research and Diversity in Latin America (pp. 359-402). Berlín: Springer Heidelberg.

Byrne, M. (2011). Impact of ocean warming and ocean acidification on marine invertebrate life history stages: vulnerabilities and potential for persistence in a changing ocean. Oceanography and Marine Biology: an Annual Review, 49, 1-42.

Byrne, M. (2012). Global change ecotoxicology: identification of early life history bottlenecks in marine invertebrates, variable species responses and variable experimental approaches. Marine Environmental Research, 76, 3-15.

Byrne, M., Sewell, M. A. \& Prowse, T. A. A. (2008a). Nutritional ecology of sea urchin larvae: Influence of endogenous and exogenous nutrition on echinopluteal growth and phenotypic plasticity in Tripneustes gratilla. Functional Ecology, 22(4), 643-648.

Byrne, M., Prowse, T.A.A., Sewell, M.A., Dworjanyn, S., Williamson, J.E. \& Vaïtilingon, D. (2008b). Maternal provisioning for larvae and larval provisioning for juveniles in the toxopneustid sea urchin Tripneustes gratilla. Marine Biology, 155(5), 473-482.

Byrne, M., Ho, M., Selvakumaraswamy, P., Nguyen, H.D., Dworjanyn, S.A. \& Davis, A.R. (2009). Temperature, but not $\mathrm{pH}$, compromises sea urchin fertilization and early development under near-future climate change scenarios. Proceedings of the Royal B: Society Biological Sciences, 276(1663), 1883-1888.

Catarino, A., De Ridder, I., Gonzalez, C., Gallardo, M.P. \& Dubois, P. (2012). Sea urchin Arbacia dufresnei (Blainville 1825) larvae response to ocean acidification. Polar Biology, 35(3), 455-461.

De Vido de Mattio, N. (1980). Influencia de la temperatura $y$ de la producción primaria en la variación estacional de la composición química y peso de Aulacomya Ater Ater en Golfo Nuevo.Chubut. Argentina: Centro Nacional Patagónico-CONICET.

InfoStat Release 2016. Grupo InfoStat, FCA, Universidad Nacional de Córdoba, Argentina. Retrived from http://www. infoestar. com. ar.

Epherra, L. (2016). Evaluación del impacto de invertebrados herbivoros nativos sobre el alga invasora Undaria pinnatifida: Arbacia dufresnii (Echinodermata: Echinoidea) como modelo de estudio (Doctoral dissertation). Universidad Nacional de Mar del Plata, Argentina.

Epherra, L., Gil, D., Rubilar, T., Perez-Gallo, A.S., Reartes, B. \& Tolosano, J.A. (2015). Temporal and spatial differences in the reproductive biology of the sea urchin Arbacia dufresnii. Marine and Freshwater Research, 66(4), 329-342.

Ericson, J. A., Ho, M. A., Miskelly, A., King, C. K., Virtue, P., Tilbrook, B. \& Byrne, M. (2012). Combined effects of two ocean change stressors, warming and acidification on fertilization and early development of the Antarctic echinoid Sterechinus neumayeri. Polar Biology, 35(7), 1027-1034.

Esteves, J.L., de Vido de Mattio, N., Cejas, J.J. \& Frontali, J. (1981). Evolución de parámetros químicos y biológicos en el área de Bahía Nueva (Golfo Nuevo). Argentina: Centro Nacional Patagónico-CONICET.

Esteves, J.L., Santinelli, N., Sastre, V., Díaz, R. \& Rivas, O. (1992). A toxic dinoflagellate bloom and PSP production associated with upwelling in Golfo Nuevo, Patagonia, Argentina. Hydrobiologia, 242(2), 115-122.

Ettensohn, C. A. (2017). Sea urchins as a model system for studying embryonic development. In M. J. Caplan. (Ed.), Reference Module in Biomedical Sciences (pp. 1-7). Ámsterdam: Elsevier.

Fernández, J. P., Epherra, L., Sepúlveda, L. \& Rubilar, T. (2019). Desarrollo embrionario y larval del erizo de mar verde Arbacia dufresnii (Echinodermata: Echinoidea). Naturalia Patagónica. 15, 44-58.

Fujisawa, H. (1995). Variation in embryonic temperature sensitivity among groups of the sea urchin, Hemicentrotus pulcherrimus, which differ in their habitats. Zoological Science, 12(5), 583-589. 
García, E., Clemente, S. \& Hernández, J.C. (2015). Ocean warming ameliorates the negative effects of ocean acidification on Paracentrotus lividus larval development and settlement. Marine Environmental Research, 110, 61-68.

George, S.B., Cellario, C. \& Fenaux, L. (1990). Population differences in egg quality of Arbacia lixula (Echinodermata: Echinoidea): proximate composition of eggs and larval development. Journal of Experimental Marine Biology and Ecology, 141, 107-118.

Gianguzza, P. (2020). Arbacia. In J. M Lawrence (Ed.). Sea Urchins: Biology and Ecology. (43, pp. 419-429). Ámsterdam: Elsevier.

Gianguzza, P., Agnetta, D., Bonaviri, C., Di Trapani, F., Visconti, G., Gianguzza, F. \& Riggio, S. (2011). The rise of thermophilic sea urchins and the expansion of barren grounds in the Mediterranean Sea. Chemistry and Ecology, 27 (2), 129-134.

Gianguzza, P., Visconti, G., Gianguzza, F., Vizzini, S., Sarà, G. \& Dupont, S. (2014). Temperature modulates the response of the thermophile sea urchin Arbacia lixula early life stages to CO2-driven acidification. Marine Environment. Research, 93, 70-77.

Gibson, R., Atkinson, R., Gordon, J., Smith, I. \& Hughes, D. (2011). Impact of ocean warming and ocean acidification on marine invertebrate life history stages: vulnerabilities and potential for persistence in a changing ocean. Oceanography Marine Biology Annual Review, 49, 1-42.

Gilbert, S. F. (2005). Biología del desarrollo. Buenos Aires: Editorial Médica Panamericana.

Hardy, N.A., Lamare, M., Uthicke, S., Wolfe, K., Doo, S. \& Dworjanyn, S. (2014). Thermal tolerance of early development in tropical and temperate sea urchins: inferences for the tropicalization of eastern Australia. Marine Biology, 161(2), 395-409.

Irvine, S.Q. (2020). Embryonic canalization and its limitsA view from temperature. Journal of Experimental Zoology Part B: Molecular and Developmental Evolution, 334(2), 128-144.

Karelitz, S., Lamare, M., Patel, F., Gemmell, N. \& Uthicke, S. (2020). Parental acclimation to future ocean conditions increases development rates but decreases survival in sea urchin larvae. Marine Biology, 167(1), $1-16$.

Lemire, M. \& Himmelman, J.H. (1996). Relation of food preference to fitness for the green sea urchin, Strongylocentrotus droebachiensis. Marine Biology, 127(1), 73-78.

Lessios, H.A., Lockhart, S., Collin, R., Sotil, G., SanchezJerez, P., Zigler, K.S. \& Vacquier, V.D. (2012). Phylogeography and bindin evolution in Arbacia, a sea urchin genus with an unusual distribution. Molecular Ecology, 21(1), 130-144.

McCullagh, P. (1984). Generalized linear models. European Journal of Operational Research, 16(3), 285-292.

Metaxas, A. (2013). Larval ecology of echinoids. In J.M. Lawrence (Ed.), Developments in Aquaculture and Fisheries Science (pp. 69-81). San Diego, USA: Elsevier Academic Press.

Newcombe, E.M., Cárdenas, C.A. \& Geange, S. (2012). Green sea urchins structure invertebrate and macroalgal communities in the Magellan Strait, southern Chile. Aquatic Biology, 15, 135-144.

O’Connor, C. \& Mulley, J.C. (1977). Temperature effects on periodicity and embryology, with observations on the population genetics, of the aquacultural echinoid Heliocidaris tuberculata. Aquaculture, 12(2), 99-114.

O’Connor, M.I., Bruno, J.F., Gaines, S.D., Halpern, B.S., Lester, S.E., Kinlan, B.P. \& Weiss, J.M. (2007). Temperature control of larval dispersal and the implications for marine ecology, evolution, and conservation. Proceedings of the National Academy of Sciences, 104(4), 1266-1271.

Parra, M., Rubilar, T., Latorre, M., Epherra, L., Gil, D. \& Díaz de Vivar, M. (2015). Nutrient allocation in the gonads of the sea urchin Arbacia dufresnii in different stages of gonadal development. Invertebrate Reproduction \& Development, 59(1), 26-36.

Pastor, C. T. \& Bala, L. O. (1995). Estudios de base en la bahía de Puerto Madryn (Golfo Nuevo, Chubut): parámetros químicos. Naturalia Patagónica, 3, 41-56.

Penchaszadeh, P. \& Lawrence, J. (1999). Arbacia dufresnii (Echinodermata: Echinoidea): a carnivore in Argentinian waters. In M.D. Candia Carnevali \& F. Bonasoro (Eds.), Echinoderm Research (pp. 525-530). Rotterdam, The Netherlands: A.A. Balkema.

Pérez-Portela, R., Wangensteen, O. S., Garcia-Cisneros, A., Valero-Jiménez, C., Palacín, C. \& Turon, X. (2019). Spatio-temporal patterns of genetic variation in Arbacia lixula, a thermophilus sea urchin in expansion in the Mediterranean. Heredity, 122(2), 244-259.

Pörtner, H. O. (2002). Climate variations and the physiological basis of temperature dependent biogeography: systemic to molecular hierarchy of thermal tolerance in animals. Comparative Biochemistry Physiology Part A. Molecular \& Integrative Physiology, 132(4), 739-761.

Privitera, D., Noli, M., Falugi, C. \& Chiantore, M. (2011). Benthic assemblages and temperature effects on Paracentrotus lividus and Arbacia lixula larvae and settlement. Journal of Experimental Marine Biology and Ecology, 407(1), 6-11. 
Przeslawski, R., Byrne, M. \& Mellin, C. (2015). A review and meta-analysis of the effects of multiple abiotic stressors on marine embryos and larvae. Global Change Biology, 21(6), 2122-2140.

Rahman, M.S., Rahman, S.M., \& Uehara, T. (2007). Effects of temperature on early development of the sea urchin Echinometra mathaei from the intertidal reef of Okinawa Island, Japan. Journal of the Japanese Coral Reef Society, 9(1), 35-48.

Rahman, S., Tsuchiya, M. \& Uehara, T. (2009). Effects of temperature on hatching rate, embryonic development and early larval survival of the edible sea urchin, Tripneustes gratilla. Biologia, 64(4), 768-775.

Rivas, A.L., Pisoni, J.P. \& Dellatorre, F.G. (2016). Thermal response to the surface heat flux in a macrotidal coastal region (Nuevo Gulf, Argentina). Estuarine, Coastal and Shelf Science, 176, 117-123.

RStudio Team (3.5.1) [Software]. (2020). RStudio: Integrated Development for R. RStudio, PBC, Boston, MA URL. Retrieved from http://www.rstudio.com/.

Rubilar, T., Epherra, L., Deias-Spreng, J., De Vivar, M.E., Avaro, M., Lawrence, A.L. \& Lawrence, J.M. (2016). Ingestion, Absorption and Assimilation Efficiencies, and Production in the Sea Urchin Arbacia dufresnii Fed a Formulated Feed. Journal Shellfish Research, 35(4), 1083-1093.

Sewell, M.A. \& Young, C.M. (1999). Temperature limits to fertilization and early development in the tropical sea urchin Echinometra lucunter. Journal of Experimental Marine Biology and Ecology, 236, 291-305.

Thompson, R.J. (1983). The Relationship between Food Ration and Reproductive Effort in the Green Sea
Urchin, Strongylocentrotus droebachiensis. Oecologia, 56(1), 50-57.

Uthicke, S., Schaffelke, B. \& Byrne, M. (2009). A boombust phylum? Ecological and evolutionary consequences of density variations in echinoderms. Ecological Monographs, 79(1), 3-24.

Visconti, G., Gianguzza, F., Butera, E., Costa, V., Vizzini, S., Byrne, M. \& Gianguzza, P. (2017). Morphological response of the larvae of Arbacia lixula to near-future ocean warming and acidification. ICES Journal of Marine Science, 74(4), 1180-1190.

Walker, C.W. \& Lesser, M.P. (1998). Manipulation of food and photoperiod promotes out-of-season gametogenesis in the green sea urchin, Strongylocentrotus droebachiensis: implications for aquaculture. Marine Biology, 132(4), 663-676.

Walker, C. W., Lesser, M. P. \& Unuma, T. (2013). Sea urchin gametogenesis-structural, functional and molecular/genomic biology. In J. M Lawrance (Ed.), Developments in Aquaculture and Fisheries Science (pp. 25-43). Ámsterdam: Elsevier.

Wangensteen, O. S., Turon, X., Casso, M. \& Palacín, C. (2013). El ciclo reproductivo del erizo de mar Arbacia lixula en el noroeste del Mediterráneo: influencia potencial de la temperatura y el fotoperíodo. Biología Marina, 160(12), 3157-3168.

Wong, J. M., Kozal, L. C., Leach, T. S., Hoshijima, U. \& Hofmann, G., E. (2019) Transgenerational effects in an ecological context: Conditioning of adult sea urchins to upwelling conditions alters maternal provisioning and progeny phenotype. Journal of Experimental Marine Biology and Ecology, 517, 65-77.

Zar, J.H. (1984). Biostatistical Analysis-Prentice-Hall Inc. New Jersey, USA: Englewood Cliffs. 